\title{
MANAGEMENT OF VENOMOUS SNAKEBITES IN DOGS AND CATS IN BRAZIL
}

\section{FERREIRA JÚNIOR R.S. ${ }^{1}$; BARRAVIERA B. ${ }^{1,2}$}

${ }^{1}$ Center for the Study of Venoms and Venomous Animals (CEVAP), São Paulo State University (UNESP), Botucatu, São Paulo, Brazil; ${ }^{2}$ Department of Tropical Medicine and Imaging Diagnosis, Botucatu School of Medicine, UNESP, Botucatu, São Paulo, Brazil.

\begin{abstract}
Snake envenoming is a major problem both to veterinary and human medicine in tropical countries due to high incidence, severity, and sequelae. In Brazil, most envenomings involving animals are caused by Bothrops and Crotalus snakes; these are the highest risk to animals. This study reports on Bothrops and Crotalus envenomings in dogs, the main species responsible for epidemiology, pathogenesis, venom action, clinical signs, sequelae and complications, clinical pathology, necropsy findings, diagnosis, and treatment. Veterinarians must be capable of identifying the snake not only by observing its characteristics but also symptom evolution.
\end{abstract}

KEY WORDS: snakes, Bothops, Crotalus, dog.

\section{CORRESPONDENCE TO:}

R. S. FERREIRA JÚNIOR - CEVAP, UNESP, Caixa Postal 577, 18618-000, Botucatu, São Paulo, Brasil.

E-mail rseabra@cevap.org.br 


\section{INTRODUCTION}

Envenomings are a major public health problem for developing countries due to high incidence, severity, and sequelae $(12,13,48,62,66,69,70,77)$. This extends to veterinary medicine due to the great damage mainly to cows (19) and pets, such as dogs (43).

Snakes are reptiles known mainly by their elongated flexible bodies and anatomical modifications that allow them to feed on large preys, by swallowing them whole $(38,45)$.

Brazilian venomous snakes belong to the Viperidae and Elapidae families; the first includes the Bothrops (Figure 1), Crotalus (Figure 2), and Lachesis genera; the second the Micrurus genus $(28,33,35,38,70)$.

In Brazil, most envenomings are caused by Bothrops and Crotalus snakes; these are the highest risk to animals (19).

The Bothrops genus (Table 1) includes viviparous, aggressive snakes, which show the following characteristics: mobile fangs, smooth tail, and loreal pit. This genus includes over 30 species showing different color patterns, ranging from green to black. Habits vary according to species and age; they can be found on trees, hidden near water courses, or humid areas. They may feed on small amphibians, rodents, and birds. Adult snakes are from 0.4 to 2.0 meters in length, and can be found throughout the country $(28,31,33-35,38,52,57,70)$.

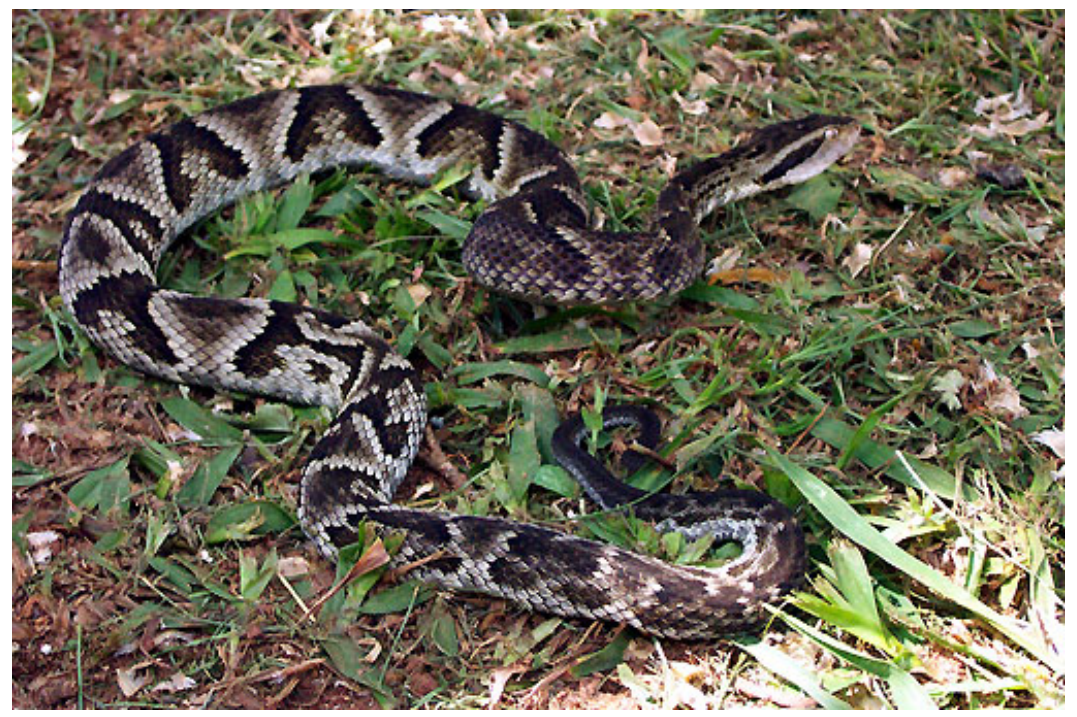

Figure 1. Bothrops jararaca (jararaca). 
Crotalus snakes are viviparous and show a rattle on the tail, mobile fangs, and loreal pit. They are found in dry and rocky environments of low and open vegetation; they are rarely found in jungles. Except for the strike, these snakes are slow moving, not very aggressive, and feed on rodents. In Brazil, there is only one species with six subspecies (Table 1), of about 1.20 meters in length $(28,31,33-35,38,52,57,70)$.

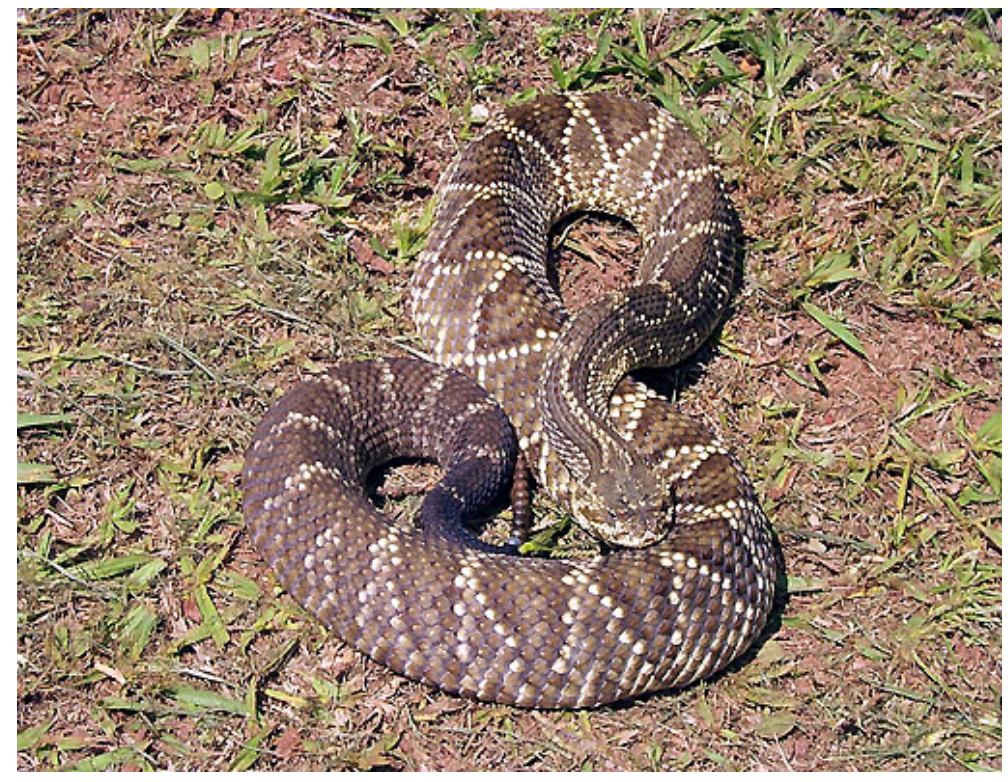

Figure 2. Crotalus durissus terrificus (rattlesnake).

In Brazil, $80 \%$ to $90 \%$ of the envenomings are caused by Bothrops snakes; $8 \%$ to $20 \%$ by Crotalus snakes $(9,10,13,15,16,21,25,30,33,36,56,63,68)$.

In human medicine, epidemiological data are relatively well established. Since 1986, the Ministry of Health has made snake envenoming notifications mandatory. According to the Ministry of Health data, approximately 20,000 envenomings are reported every year; about 2,000 of these in São Paulo State $(6,8-13,23,26,67,69)$.

In the Botucatu region in central-western São Paulo State, $80 \%$ of the envenomings are caused by B. jararaca, B. alternatus, and B. neuwidii and $20 \%$ by Crotalus durissus terrificus (9-11).

According to Bicudo (19), statistics about domestic envenomings are scarce in veterinary literature (32). 
In a retrospective study performed at the Hospital Veterinário da Faculdade de Medicina Veterinária e Zootecnia of UNESP, Botucatu, Estado de São Paulo, 149 envenoming records were found, of which 128 had been caused by Bothrops, 11 by Crotalus, and 10 had not been identified. Of these, 103 were in dogs, 22 in horses, 17 in cows, 4 in goats, 2 in cats, and 1 in pigs (20). Most envenomings occur in spring and summer (October to March) $(9,13,23,33,54)$.

Table 1. Zoological classification, common names, and distribution of the main Bothrops and Crotalus snakes in Brazil.

\begin{tabular}{|c|c|c|}
\hline Species & Common name & Distribution \\
\hline Bothrops alternatus & Urutu cruzeiro, Cruzeira, Boicotira & MG, SP, GO, MS, PR, SC, RS \\
\hline Bothrops atrox & Caiçaca, Jararaca do norte, Combóia & AM, PA, MA, RO \\
\hline Bothrops brazili & Jararaca vermelha, Surucucu vermelha & AM, PA, MT \\
\hline Bothrops castelnaudi & Jararaca cinza & AM, GO, MT \\
\hline Bothrops cotiara & Cotiara & SP, SC, PR, RS \\
\hline Bothrops erythromelas & Jararaca da seca, Jararaca & Northeastern Region \\
\hline Bothrops fonsecai & Cotiara, Jararaca & SP,RJ, MG \\
\hline Bothrops iglesiasi & Jararaquinha & PI \\
\hline Bothrops insularis & Jararaca ilhôa, Ilhôa & Ilha da Queimada Grande - SP \\
\hline Bothrops itapetiningue & Jararaca do campo, Boipeva, Furta cor & SP, MG,GO,PR,MS,SC \\
\hline Bothrops jararaca & Jararaca, Jararaquinha do rabo branco & From Bahia to Rio Grande do Sul \\
\hline Bothrops jararacussu & Jararacussu & SP, MG, ES, RJ, MG, PR, SC \\
\hline Bothrops leucurus & Jararaca, Jararaca baiana & BA \\
\hline \multirow[t]{2}{*}{ Bothrops moojeni } & Caiçaca, Jararacão & PA, MA, GO, MT, MS, MG, SP, PR \\
\hline & & Throughout the country except the \\
\hline Bothrops neuwidii & Jararaca pintada & Northern Region \\
\hline Crotalus durissus cascavella & Cascavel de quatro ventas or Cascavel & AL, CE, MA, MG, PE, PI, RN \\
\hline Crotalus durissus collilineatus & Cascavel or Maracabóia & GO, MT, MG,MS, SP \\
\hline Crotalus durissus marajoensis & Boicininga, Boiçununga, or Maracá & Ilha de Marajó \\
\hline Crotalus durissus ruruima & Boicininga, Boiçununga, or Maracá & RR,AM, PA, RO \\
\hline Crotalus durissus terrificus & Cascavel or Boiquira & AM, MT, MG, PR, RS, RO, SC, SP, PA \\
\hline Crotalus durissus trigonicus & Cascavel & $\mathrm{RR}$ \\
\hline
\end{tabular}


According to Hacket et al. (43), who studied 100 dogs bitten by rattlesnakes between 1989 and 1998, most envenomings occurred in spring and summer; there was no preference for gender, and most dogs had bites to the head in late afternoon.

\section{CHARACTERISTICS OF SNAKE ENVENOMINGS}

In relation to time elapsed between envenomings and treatment, those affecting domestic animals are quite different from humans, especially when involving animals such as bovine, equine, ovine, caprine, and bubaline raised in extensive breeding system (19).

All mammals are susceptible to snake venoms, but domestic animal's susceptibility is different. The most sensitive species in decreasing order are: bovine, equine, ovine, caprine, canine, and swine; feline being the most resistant $(19,24,37,51,54)$.

In relation to pets, such as cats and dogs, they are generally treated over 1 to 2 hours after the bite, when the clinical symptoms are evident.

In animal envenoming, the snake is rarely identified or captured (19); when the snake is brought to the veterinarian, it is usually mutilated, which makes identification difficult (27).

\section{Pathogenesis}

Snake venoms consist of simple and complex substances, whose proportion and specific characteristics vary depending on the different species.

About $90 \%$ to $95 \%$ of venom dry weight consists of protein, and some protein fractions are biologically more important than the non-protein ones, with specific chemical and biological activities $(34,42,73)$.

\section{Bothrops envenoming}

Bothrops venom is composed of hyaluronidase, responsible for absorption and dispersal in the tissues; hematoxin and cytolysin, which cause local inflammation, necrosis, and vascular epithelium damage; and phospholipase $\mathrm{A}_{2}$ and esterase, which alter membrane permeability releasing histamine and bradykynin (42,58-60,73).

Phospholipase A2 activity is present in all Bothrops venoms, except in that of Bothrops cotiara (78). Bothrops snakes possess venoms with coagulant, proteolytic, and vasculotoxic effects. 
Bothrops venom coagulant action is known for its thrombin-like fraction and is also present in Crotalus venom (51,59). Most Bothrops venoms, isolated or simultaneously, activate the X factor and prothrombin. They also show a thrombin-like effect, transforming fibrinogen into fibrin. These produce fibrin and fibrinogen degradation, which may cause blood incoagulability $(9,12,13,29,49,64)$.

This condition is similar to that of disseminated intravascular coagulation (DIC), forming microcoagula and compromising several organs $(7,9,13,23,33)$.

The necrotic action, also called proteolytic, results from the direct citotoxic action in tissues by venom proteolytic fractions, which induce release of vasoactive substances, such as bradykynin and histamine, causing extensive local reaction including pain, edema, congestion, hemorrhage, and necrosis $(13,32,40,41,65,71,74)$. These lesions can be potentialized by secondary infections $(9,12,13)$.

The systemic vasculotoxic action is caused by hemorrhagic factors called hemorrhagins. They act on blood vessels, first destroying the basal membrane, and then causing its rupture. Hemorrhage may be local or systemic in the lungs, brain, and kidneys. Edema at the bite site, which generally occurs minutes after envenoming, results from a toxic injury in the blood vessel endothelium $(9,12,13,29,60,65,78)$.

Bothrops envenomings may be followed by shock, with or without a defined cause. It presents hypovolemia due to blood or plasma loss in the edematous limb; thus activation of hypotensive substances, pulmonary edema, and disseminated intravascular coagulation may occur $(9,12,22,33,34)$.

Renal failure $(1,9,10,12,22)$ may occur by venom direct action or secondary to complications where shock is present. Formation of microthrombi by coagulant and vasculotoxic lesions is believed to be capable of producing renal ischemia due to microcirculation obstruction.

\section{Crotalus envenoming}

Composition of Crotalus venom is complex, consisting of enzymes, toxins, and peptides. The main toxins are: crotamine, crotapotin, phospholipase A2, giroxin, and convulxin (9).

The venom has major effects on skeletal muscles, central nervous system (CNS), kidneys, and blood; other organs such as the liver may also be affected $(6,7,9,15,17)$. 
The myotoxic action causes lesions in skeletal muscular fibers (rhabdomyolysis) with enzyme and myoglobin release into blood, which are then excreted through urine $(3-5,50)$. Experimentally, rhabdomyolysis is due to crotoxin and crotapotin local action (9).

Neurotoxic actions affect both the peripheral and the CNS. They are mainly produced by the crotoxin fraction, a neurotoxin with pre-synaptic action on nerve endings, inhibiting acethylcholine release. This inhibition is the main factor responsible for the neuromuscular block, which causes motor paralysis in animals $(6,9,11)$.

There are hematological and coagulant alterations related to the erythrocytes, lymphocytes, platelets, and coagulation factors. Leukocytosis occurs, with polymorphonuclear cell predominance $(47,61)$. In general, there is no reduction in platelet number, and hemorrhagic manifestations are mild (10).

Renal alterations may be caused by a direct venom action on the cells or an indirect one caused by myoglobinuria resulting from rhabdomyolysis and other factors such as dehydration, blood hypertension, metabolic acidosis, and shock. They may be associated with rhabdomyolysis and contribute to renal lesion $(6,10,23,33,50)$.

Hepatic alterations caused by Crotalus venom were first reported in 1989 by Barraviera et al. (14). These authors demonstrated experimental hepatic lesions in Wistar rats injected with Crotalus durissus terrificus venom $(9,15)$.

\section{Clinical Signs}

Severity of the envenoming depends on several factors: snake genus and species, bitten animal species, animal size, time until treatment, volume injected, bite site, and symptom intensity $(18,34)$.

Local reaction is rapid, intense, and can be seen up until two hours after the envenoming $(34,71)$.

Edema at bite site (Figure 3) is the most evident symptom of Bothrops envenoming; its severity is directly proportional to the time elapsed since venom injection $(32,41)$.

Palpation in the bite site area shows major edema pain (32,34).

Most animals show weakness, lack of appetite, and increased heart beat and breathing $(19,31)$. 
Two small hemorrhagic marks can be seen at the bite site, but they are not always identified $(31,34)$. Bleeding by the nose, mouth, and skin can be seen in the most severe cases (19).

Hemorrhage and the significant increase in coagulation time are indications of envenoming severity and the large quantity of injected venom.

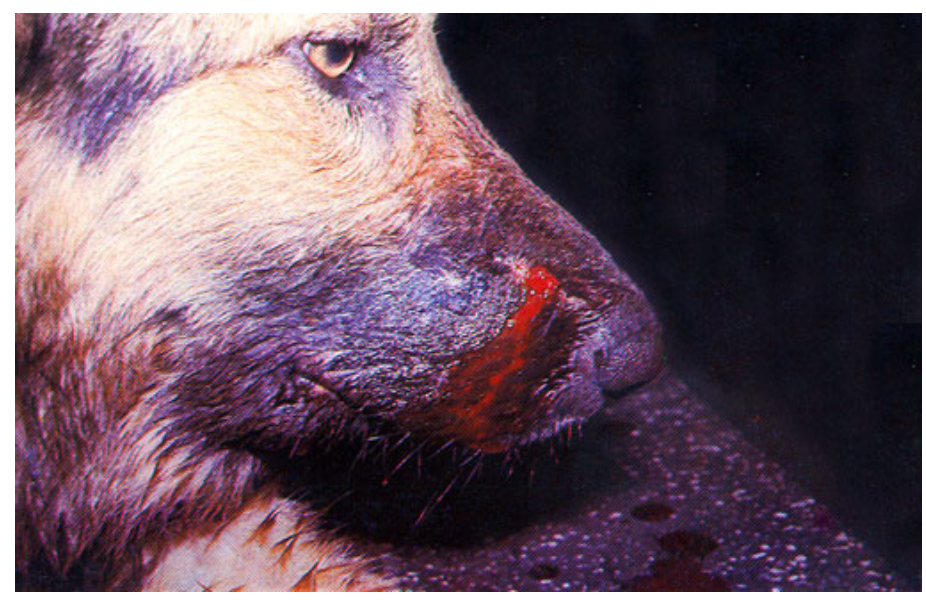

Figure 3. Dog muzzle bitten by Bothrops snake. Photograph kindly provided by Prof. Dr. Pedro Luis Bicudo.

In these cases, in addition to external hemorrhage, there may be massive hemorrhage in the subcutaneous tissue, at the bite site, in the thoracic and abdominal cavities, and sometimes in the CNS. Anemia in these cases is quite evident.

When the animal is bitten in the head, generally in the muzzle, local reaction can cause severe edema, which may reach the lower jaw, neck, and thoracic region. In dogs with difficulty in keeping the mouth closed due to edema, mouth breathing produce snores $(19,31,57)$.

Pain is quite evident, especially at bite site, preventing the animals from moving with great difficulty $(19,31,32)$.

Envenomings in the mouth and tongue can prevent the animal from eating and drinking, which causes dehydration $(19,31)$.

When the upper respiratory tract is obstructed, dyspnea and respiratory failure may occur due to glottis edema, and tracheotomy is the indicated emergency procedure to ensure animal survival $(19,31,44)$. In Crotalus envenoming fang marks are not always seen. The most 
evident symptoms of Crotalus envenoming are: dark urine (myoglobinuria), blindness, difficulty walking, and immobility $(19,31,43)$. The animal also shows difficulty in supporting the head weight, eye paralysis, and decreased or absent eyelid movements (31). As the symptoms progress, the dogs show total weakness and absence or difficulty responding when stimulated by the owner.

\section{Sequelae and complications}

Bite site contamination may be a major factor for necrosis establishment. Bacteria from mouth microbiota, venom in snake glands, substances applied on the wound, incisions made with sharp instruments, and the environment itself can be found at the bite site (33).

Jorge and Ribeiro (46) found that in approximately 9\% of human envenoming abscess formation occur due to the presence of the following microbial agents: Morganela morganii, Proteus rettgeri, Enterobacter spp, Escherichia coli, Enterococcus spp, and Bacterioides spp.

Mortality by Bothrops envenoming is low, but major sequelae can limit the animal's physical capacity if it does not receive appropriate treatment (32).

Muscular necrosis (Figure 4) is a relevant local effect that may lead to permanent tissue loss, disability, and amputation (19,32).

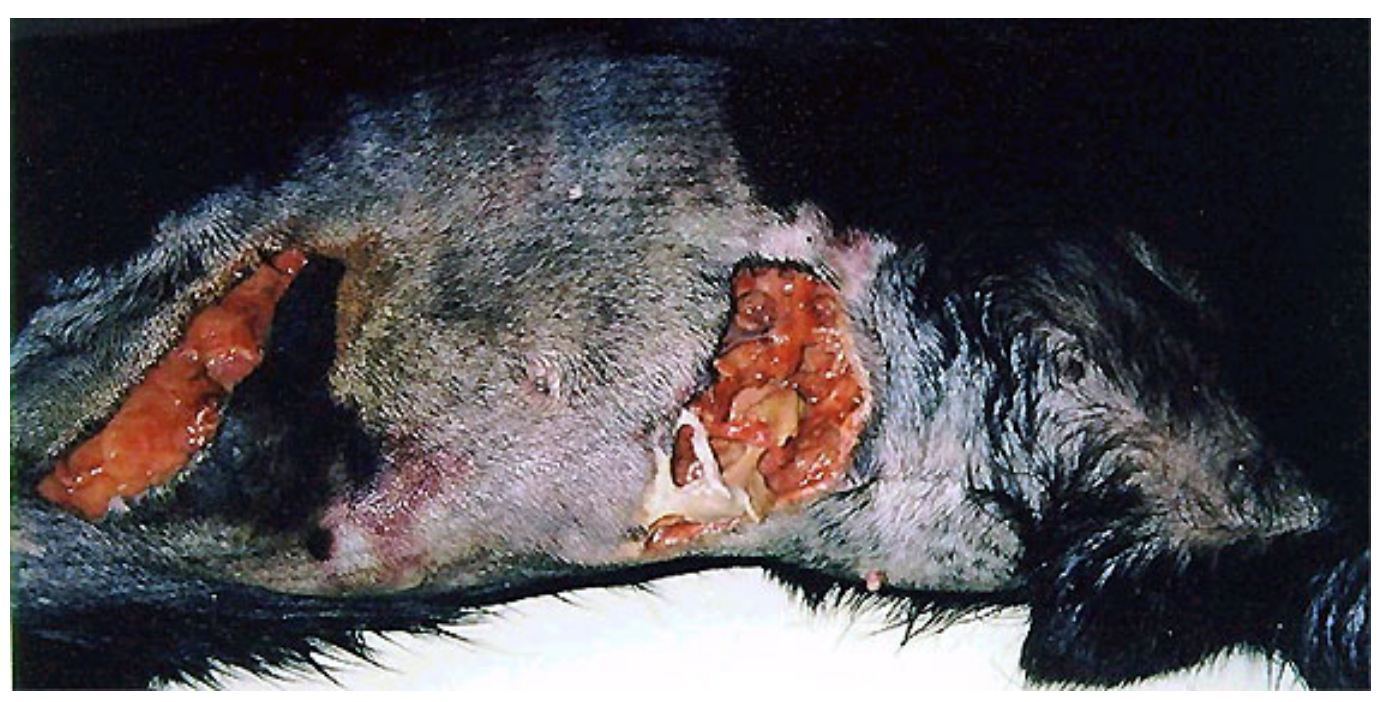

Figure 4. Tissue necrosis in the left lateral region of a dog twelve days after Bothrops envenoming. 
In severe Crotalus envenoming, the animal may develop acute renal failure (20). According to Guidolin et al. (39), another major complication is bite site contamination by Clostridium tetani, which may cause tetanus.

\section{Clinical Pathology}

In humans there is leukocytosis with neutrophilia; lymphopenia; and increased coagulation time, C-reactive proteins, and mucoproteins. On the first days after envenoming, there is a decrease of total proteins and albumin (15). According to Barraviera et al. (15), the cytokines responsible for acute phase reaction are increased on the first days after envenoming.

Takahira (72) injected Bothrops jararaca venom in dogs and observed a significant decrease in platelet, red blood cell, lymphocyte, eosinophil, and megacariocyte total count. There may be alterations in globular volume, fibrinogen, hemoglobin, total plasma protein, urea, creatinine, serum protein, and albumin. There was a significant increase in leucocyte, polymorphonuclear neutrophil, and monocyte total count; in fibrin degradation product levels; alanine aminotransferase; alkaline phosphatase; and creatine kinase. This author also reported that coagulation, thromboplastin, partial activated thromboplastin, protrhombin, and thrombin times were significantly increased in the dogs.

Bothrops venom can elevate creatine kinase serum activity in rats, demonstrating the venom harmful activity in muscular tissue (53).

\section{Necropsy Findings}

Intense, thick, gelatinous, and yellowish serous hemorrhagic edema with coagulated blood is seen at the bite site. If the lesion is recent, necrotic tissue and suppurative secretion are observed $(18,19,31)$.

Manifestations in other organs are generalized pulmonary emphysema, hemorrhagic areas in the epicardium, miocardium, endocardium, lungs, gastrointestinal tract, bladder, and kidneys (18).

Histopathological lesions include severe congestion and hemorrhage in most organs, acute tubular necrosis, and sometimes, acute glomerulonephritis, interstitial nephritis, and renal cortical necrosis $(31,34)$. 


\section{Diagnosis}

Most envenoming diagnoses are difficult because the owner did not see the moment of the bite nor the offending animal was captured for identification. However, during anmnesis, important data, such as the presence of snakes in the region, report of other envenomings and evolution of clinical signs may give a clue about the snake genus and type of treatment. Clinical confirmation is made by laboratory tests and success of the therapy used.

\section{Treatment}

Serotherapy is so far the only effective treatment for snake-bitten animals. Specific antivenom should always be used according to the offending snake genus $(19,33,44)$. The envenoming can be identified by the symptoms, direct snake identification, or prevalent distribution of the snake genera in that region (32).

Antivenoms are produced by inoculating sub-lethal doses of different snake venoms in equine; Bothrops and Crotalus antivenoms are produced in this manner. Snake antivenom (antiophidic serum) is a pool of Bothrops and Crotalus antivenoms with the capacity of neutralizing both above venoms $(55,75,77)$.

When the offending animal identification is doubtful and there is no specific antivenom available, antiophidic serum should be used; this latter being easily found in the market.

Araujo and Belluomini (2) report that in animals experimentally injected with Crotalus venom, serotherapy was more effective the shorter the interval between venom injection and treatment.

Ferreira Júnior and Barraviera (32) observed in one case limited efficacy of antivenom serotherapy in preventing local tissue damage development in Bothrops envenoming. This is corroborated by other authors $(49,59,60)$.

Hackett et al. (43) studied American rattlesnake-envenomed dogs with high morbidity and low mortality. They report that antivenom administration to dogs is questionable.

Treatment is based on the quantity of injected venom. In Bothrops envenomings, the quantity of antivenom should be sufficient to neutralize at least $100 \mathrm{mg}$ of venom. In Crotalus envenomings, the antivenom should neutralize at least $50 \mathrm{mg}(19,31,33)$. 
Commercial antivenom is standardized so as one milliliter $(1 \mathrm{ml})$ neutralizes two milligrams (2 mg) of Bothrops venom and one milligram (1 mg) of Crotalus venom. Therefore, the minimum quantity of antivenom used in Crotalus or Bothrops envenomings is 50 milliliters regardless of the animal size $(19,31,33)$.

Total antivenom volume should be slowly injected intravenously (IV), if possible diluted in $5 \%$ saline or glucose and administered. When it is not possible to administer the antivenom $\mathrm{IV}$, it should be done intraperitoneally, or as the last resource, intramuscularly and subcutaneously $(19,27,58)$. In these latter cases, the antivenom cannot be diluted in glucose solution. Antivenom should never be injected or infiltrated into the bite site (19).

Larger doses of antivenom and the need for repeated treatment should be considered in cases of symptom remission or after consulting a veterinarian.

Antivenoms with expired validity still have the capacity of neutralizing venoms, and their use should only be considered when valid antivenom is unavailable or the animal's life is at risk. To this end, the following precautions must be taken:

- never inject the antivenom IV, but intramuscularly or subcutaneously;

- the neutralizing capacity of the expired antivenom is reduced to half; therefore, a double dose should be used;

- antivenom with precipitate in the bottom of the vial should not be used;

- when using expired antivenom, it is of major importance to observe possible anaphylactic reactions.

\section{Complementary treatments}

The envenomed animals should be observed for at least 72 hours, kept in quiet and comfortable places, without being moved or manipulated $(19,34)$.

Cuts should never be made at the bite site; these not only worsen the animal's pain but may also cause severe infection and hemorrhage due to hemorrhagic factors present in the venoms (31).

The animals unable to drink water should be properly hydrated with electrolytic solutions by parenteral route. In Crotalus envenomings, parenteral feeding is of major importance to prevent acute renal failure $(19,31)$. 
Osmotic diuresis can be induced using 20\% (0.25 to $0.5 \mathrm{~g} / \mathrm{kg}$ ) mannitol, with repetitions every 4 to 6 hours if necessary $(19,31,76)$.

In case of persisting oliguria, diuretic as furosemide should be administered IV, 2 to $4 \mathrm{mg} / \mathrm{kg}$ every 8 to 12 hours if necessary $(19,31,76)$.

Anaphylactic reaction symptoms caused by antivenom are rare in animals and should be treated according to severity with adrenalin-type medications, anti-histamines, and corticosteroids. Antivenom administration must be temporarily interrupted (19).

According to Bicudo (19), alternative treatments using anti-inflammatories, steroids, or nonsteroids have no influence on the animal's survival prognosis.

Antibiotics should be used considering lesion extent at bite site (32).

Necrosis areas should be treated as open wounds using anti-septic solutions and ointments to promote healing (31).

Sequelae almost always result from necrosis complications or secondary infections at the bite site (41).

As snakebites can inject pathogenic microorganisms, tetanus prophylaxis should be considered $(19,31,39)$.

Although properly treated, animal complete recovery can take weeks; therefore, they should move only when necessary.

\section{CONCLUSIONS}

Most animal envenomings are caused by Bothrops snakes. Envenomings by Crotalus present more risk to the animal's life.

Serotherapy is so far the only treatment for snake-bitten animals. It is used to neutralize the maximum quantity of venom in the shortest time; its efficacy is higher the shorter the time elapsed, preventing venom local and systemic effects.

The veterinarian should be prepared to identify the snake by its characteristics, but also by observing symptom evolution. 


\section{REFERENCES}

1 AMARAL CFS., DA SILVA OA., GODOY P., MIRANDA, D. Renal cortical necrosis following Bothrops jararaca and Bothrops jararacussu snake bite. Toxicon, 1985, 23, 877-85.

2 ARAUJO P., BELLUOMINI HE. Toxicidade de venenos ofídicos, I: sensibilidade específica de animais domésticos e de laboratório. Mem. Inst. Butantan, 1960-1962, 30, 133-42.

3 AZEVEDO-MARQUES MM., CUPO P., AMARAL CFS., HERING SE. Rattlesnake bites. Clinical features and complementary tests. Mem. Inst. Butantan, 1990, 52, 27 30.

4 AZEVEDO-MARQUES MM., CUPO P., COIMBRA TM., HERING SE., ROSSI MA., LAURE CJ. Myonecrosis, myoglobinuria and acute renal failure induced by South American rattlesnake (Crotalus durissus terrificus) envenomation in Brazil. Toxicon, 1985, 23, 631-6.

5 AZEVEDO-MARQUES, MM., HERING SE., CUPO P. Evidence that Crotalus durissus terrificus (South American rattlesnake) envenomation in humam causes myolysis rather than hemolysis. Toxicon, 1987, 11, 1163-8.

6 BARRAVIERA B. Acidentes por serpentes do gênero Crotalus. Arq. Bras. Med., 1990, 64, $14-20$.

7 BARRAVIERA, B. Alterações hepáticas no acidente crotálico. Rev. Soc. Bras. Med. Trop., 1991, 24 (supl. 2), 75-81.

8 BARRAVIERA B. O ensino dos acidentes por animais peçonhentos nas escolas médicas brasileiras. Rev. Soc. Bras. Med. Trop., 1992, 25, 203-4.

9 BARRAVIERA B. Acidentes por serpentes dos gêneros Crotalus e Micrurus. In: BARRAVIERA B. Venenos: aspectos clínicos e terapêuticos dos acidentes por animais peçonhentos. Rio de Janeiro: EPUB, 1999: 261-80.

10 BARRAVIERA B. Estudo clínico dos acidentes ofídicos. Rio de Janeiro: EPUB, 1999. 46p. 
R. S. Ferreira Júnior; B. Barraviera. MANAGEMENT OF VENOMOUS SNAKEBITES IN DOGS AND CATS IN BRAZIL. J. Venom. Anim. Toxins incl. Trop. Dis., 2004, 10, 2, p.126.

11 BARRAVIERA B., MEIRA DA. Estudo clínico-epidemiológico de doentes picados por serpentes venenosas, na região de Botucatu (SP). J. Bras. Med., 1994, 67, 225-231.

12 BARRAVIERA B., PEREIRA PCM. Acidentes por serpentes dos gêneros Bothrops, Lachesis e Micrurus. Arq. Bras. Med., 1991, 65, 345-55.

13 BARRAVIERA B., PEREIRA PCM. Acidentes por serpentes do gênero Bothrops. In: BARRAVIERA B. Venenos: aspectos clínicos e terapêuticos dos acidentes por animais peçonhentos. Rio de Janeiro: EPUB, 1999: 261-80.

14 BARRAVIERA B., BONJORNO JR., ARAKAKI D., DOMINGUES MAC., PEREIRA PCM., MENDES RP., MACHADO JM., MEIRA DA. A retrospective study of 40 victims of Crotalus snake bites. Analysis of the hepatic necrosis observed in one patient. Rev. Soc. Bras. Med. Trop., 1989, 22, 5-12.

15 BARRAVIERA B., LOMONTE B., TARKOWSKI A., HANSON LA., MEIRA, DA. Acute-phase reactions, including cytokines, in patients bitten by Bothrops and Crotalus snakes in Brazil. J. Venom. Anim. Toxins, 1995, 1, 11-22. (SciELO)

16 BARRAVIERA B., FERREIRA JÚNIOR RS., BICUDO PL., CHERUBINI A.

Toxinologia veterinária on-line. Rev. Educ. Contin. CRMV-SP, 2000, 3, 62-5.

17 BERCOVICI D., WHOOPI G. A systematic fracionation of Crotalus durissus terrificus venom. Mem. Inst. Butantan, 1987, 49, 69-78.

18 BERROCAL A., GUTIÉRREZ JM., ESTRADA R. Snake envenomation in bovine. Large Anim. Pract., 1998, 19, 26-7.

19 BICUDO PL. Acidentes ofídicos em Medicina Veterinária. In: BARRAVIERA, B. Venenos: aspectos clínicos e terapêuticos dos acidentes por animais peçonhentos. Rio de Janeiro: EPUB, 1999: 375-87.

20 BICUDO PL., BIONDO AW. Acidentes ofídicos atendidos no Hospital Veterinário da FMVZ, UNESP, Botucatu, SP, no período de 1972 a 1989. Estudo retrospectivo In: ANAIS DA MOSTRA DE PÓS-GRADUAÇÃO DA FACULDADE DE MEDICINA VETERINÁRIA E ZOOTECNIA, UNESP, 1, Botucatu. São Paulo. 1992. 
21 BORGES CC., SADAHIRO M., DOS SANTOS MC. Aspectos epidemiológicos e clínicos dos acidentes ofídicos ocorridos nos municípios do Estado do Amazonas. Rev. Soc. Bras. Med. Trop., 1999, 32, 637-46.

22 BORKOW G., GUTIÉRREZ JM., OVADIA M. Inhibition of the hemorrhagic activity of Bothrops asper venom by a novel neutralizing mixture. Toxicon, 1997, 35, 865-77.

23 BRASIL. Ministério da Saúde. Secretaria Nacional de Ações Básicas da Saúde. Manual de diagnóstico e tratamento dos acidentes por animais peçonhentos. Brasília, 1998. $241 \mathrm{p}$.

24 BÜCHEL W. Acúleos que matam. São Paulo: Revista dos Tribunais, 1979. 153p.

25 CAIAFFA WT., ANTUNES CMF., OLIVEIRA HR., DINIZ CR. Epidemiological and clinical aspects of snakebite in Belo Horizonte, Southeast Brazil. Rev. Inst. Med. Trop. São Paulo. 1997, 39, 113-8.

26 CHIPPAUX JP. Snake-bites: appraisal of the global situation. Bull. World Health Organ., 1998, 76, 515-24.

27 CLARK KA. Management of poisonous snakebites in dogs and cats. Med. Vet. Pract., 1981, 62, 421-31.

28 DA SILVA RJ. As serpentes. Jaboticabal: FUNEP, 2000. 141p.

29 DENSON KWE., RUSSEL FS., ALMAGRO D., BIPSHOP RC. Caracterization of coagulant activity of some snake venoms. Toxicon, 1972, 10, 557-62.

30 FEITOSA, R.F.G., MELO, I.M.L., MONTEIRO, H.S.A. Epidemiologia dos acidentes por serpentes peçonhentas no Estado do Ceará - Brasil. Rev. Soc. Bras. Med. Trop., 1997, 30, 295-301.

31 FERREIRA JUNIOR RS. Acidentes ofídicos. In: CEVAP. Centro Virtual de Toxinologia. Emergências veterinárias. Botucatu, UNESP, 2002. Disponível em: <www.cevap.org.br> Acesso em: 01 de novembro de 2002.

32 FERREIRA JÚNIOR RS., BARRAVIERA B. Tissue necrosis after canine Bothropic envenoming: A case report. J. Venom. Anim. Toxins, 2001, 7, 302-12. (SciELO) 
33 FERREIRA JUNIOR RS., JUNQUEIRA ME. Acidentes com animais peçonhentos. Botucatu: CEVAP, UNESP, 2000. 47p.

34 FONTEQUE JH., BARROS FILHO IR., SAKATE M. Acidentes botrópicos de interesse em animais domésticos. Rev. Educ. Contin. CRMV-SP, 2001, 4, 102-11.

35 FRANCISCO CR. Répteis do Brasil: manutenção em cativeiro. Ed. Amaro, 1997. 208p.

36 FRANCO RL., ROCHA CC., RIBEIRO LA., JORGE MT. Snakebites in Southern Minas Gerais State, Brazil. J. Venom. Anim. Toxins, 2001, 7, 56-68. (SciELO)

37 FRASER CM. Toxicology. In: THE MERCK Veterinary Manual. 7. ed. Whitehouse Station: Merck, 1991: 1729-30.

38 GREENE HW. Snakes: the evolution of mistery in nature. Berkeley: University Press, 1997. 351p.

39 GUIDOLIN R., STEPHANO MA., MORAIS JF. Production of an effective anti Bothrops: tetanus mixed hyperimmune serum of equine origin. J. Venom. Anim. Toxins, 1998, 4, 70-8. (SciELO)

40 GUTIÉRREZ JM., CERDAS L. Mecanismo de acción de miotoxinas aisladas de venenos de serpientes. Rev. Biol. Trop., 1984, 32, 213-22.

41 GUTIÉRREZ JM., LOMONTE B. Local tissue damage induced by Bothrops snake venoms.A review. Mem. Inst. Butantan, 1989, 51, 211-23.

42 GUTIÉRREZ JM., LOMONTE B. Phospholipase A2 myotoxin from Bothrops snake venoms. Toxicon, 1995, 33, 1405-24.

43 HACKETT TB., WINGFIELD WE., MAZZAFERRO EM., BENEDETTI JS. Clinical findings associated with prairie rattlesnake bites in dogs: 100 cases (1989-1998). $\boldsymbol{J}$. Am. Vet. Med. Assoc., 2002, 220, 1675-80.

44 HARNED H., OEHME FW. Poisonous snakebites in dogs and cats. Vet. Med. Small Anim. Clin., 1982, 77, 73-8. 
45 JIM J., SAKATE M. Biologia das serpentes. In: BARRAVIERA, B. Venenos: aspectos clínicos e terapêuticos dos acidentes por animais peçonhentos. Rio de Janeiro: EPUB, 1999: 109-34.

46 JORGE MT., RIBEIRO LA. Infections in the bite site after envenoming by snakes of the Bothrops genus. J. Venom. Anim. Toxins, 1997, 3, 264-72. (SciELO)

47 JORGE MT., RIBEIRO LA. Incoagulabilidade sangüínea no acidente crotálico. Rev. Soc. Bras. Med. Trop., 1988, 21, 121-33.

48 JORGE MT., RIBEIRO LA. Acidentes por animais peçonhentos. In: Amato Neto V., Baldy JLS. Doenças transmissíveis. São Paulo: Sarvier, 1989: 133-41.

49 KOUYOUMDJIAN JA., POLIZELLI C., LOBO SMA. Acidentes ofídicos causados por Bothrops moojeni na região de São José do Rio Preto, São Paulo. Arq. Bras. Med., 1990, 64, 167-71.

50 MAGALHÃES RA., RIBEIRO MMF., REZENDE NA., AMARAL CFS. Rabdomiólise secundária a acidente crotálico (Crotalus durissus terrificus). Rev. Inst. Med. Trop. São Paulo, 1986, 28, 228-33.

51 MAZAKI-TOVI M., LAVY E. Suspected Vipera palestinae envenomation in three cats. Vet. Hum. Toxicol., 1999, 41, 145-9.

52 MEJIA RA. Serpientes de Colombia: su relación con el hombre. Medellín: Secretaría de Educación y Cultura, 1987: 232.

53 MELO PA., SUAREZ-KURZ J. Interaction of Bothrops venoms and antivenim on release of creatine kinase from skeletal muscle. Braz. J. Med. Biol. Res., 1987, 20, 821-4.

54 MÉNDEZ MC., RIET-CORREA F. Snakebite in sheep. Vet. Hum. Toxicol., 1995, 37, $62-3$.

55 MORAIS JF, DE FREITAS MCW., YAMAGUCHI IK., DOS SANTOS MC., DIAS DA SILVA W. Snake antivenoms from hyperimmunized horses: Comparasion on the antivenom activity and biological properties of their whole IgG and $F(a b ')_{2}$ fragments. Toxicon, 1994, 32, 725-34. 
56 NASCIMENTO SP. Aspectos epidemiológicos dos acidentes ofídicos ocorridos no Estado de Roraima, Brasil, entre 1992 e 1998. Cad. Saúde Pública, 2000, 16, 271-6.

57 PUORTO G. Serpentes brasileiras de importância médica. In: SCHVARTSMAN S.

Plantas venenosas e animais peçonhentos. 2. ed. São Paulo: Sarvier, 1992: 143-9.

58 QUEIROZ LS., PETTA CA. Histopathological changes caused by venom of urutu snake (Bothrops alternatus) in mouse skeletal muscle. Rev. Inst. Med. Trop. São Paulo, 1984, 26, 247-53.

59 QUEIROZ LS., SANTO NETO H., ASSAKURA MT., REICHL AP., MANDELBAUM, FR. Muscular lesions induced by a hemorrhagic factor from Bothrops neuwiedi snake venom. Braz J. Med. Biol. Res., 1985, 18, 337-40.

60 QUEIROZ LS., SANTO NETO H., ASSAKURA MT., REICHL AP., MANDELBAUM FR. Pathological changes in muscle caused by haemorrhagic and proteolytic factors from Bothrops jararaca snake venom. Toxicon, 1985, 23, 341-5.

61 RAW I., ROCHA MC., ESTEVES MI., KAMIGUTI AS. Isolation and characterization of a trombine-like enzyme from the venom of Crotalus durissus terrificus. Braz. J. Med. Biol. Res., 1986, 19, 333-9.

62 REID HA., THEAKSTON RDG. The management of snake bite. Bull. World Health Organ., 1993, 61, 885-95.

63 RIBEIRO LA., JORGE MT., IVERSSON LB. Epidemiologia do acidente por serpentes peçonhentas: estudo de casos atendidos em 1988. Cad. Saúde Pública, 1995, 29, 3808.

64 ROSENFELD G., HAMPE G., KELEN EMA. Coagulant and fibrilolytic activity of animal venoms: determination of coagulant and fibrinolytic index of different species. Mem. Inst. Butantan, 1959, 29, 143-52.

65 RUCAVADO A., LOMONTE B. Neutralization of myonecrosis, hemorrhage, and edema induced by Bothrops asper snake venom by homologous and heterologous preexisting antibodies in mice. Toxicon, 1996, 34, 567-77. 
66 SALIBA, F. Estudo anatomopatológico da evolução da necrose produzida experimentalmente por venenos de Bothrops jararaca. Influência de substâncias órgano-heparinóides. Mem. Inst. Butantan, 1964, 31, 191-200.

67 SGARBI LPS., ILIAS M., MACHADO T., ALVAREZ L., BARRAVIERA B. Human envenomations due to snakebites in Marilia, State of São Paulo, Brazil. A retrospective epidemiological study. J. Venom. Anim. Toxins, 1995, 1, 70-8. (SciELO)

68 SILVEIRA PVP., NISHIOKA SA. South American rattlesnake bite in Brazilian teaching hospital. Clinical and epidemiological study of 87 cases, with analysis of factors predictive of renal failure. Trans. R. Soc. Trop. Med. Hyg., 1992, 86, 562-4.

69 SOERENSEN, B. Animais peçonhentos. São Paulo: Atheneu, 1990. 138p.

70 SOERENSEN, B. Acidentes por animais peçonhentos: reconhecimento, clínica e tratamento. São Paulo: Atheneu, 1997. 144p.

71 SOUSA JRF., MONTEIRO RQ., CASTRO HC., ZINGALI RB. Proteolytic action of Bothrops jararaca venom upon its own constituents. Toxicon, 2001, 39, 787-92.

72 TAKAHIRA, R. Hemostatic, hematological and biochemical changes in dogs induced by experimental envenomation by Bothrops jararaca (Wied, 1824) and Bothrops neuwiedi Wagler, 1824. J. Venom. Anim. Toxins, 1998, 8, 85. (SciELO)

73 VARANDA EA., GIANNINI MJSM. Bioquímica de venenos de serpentes. In: BARRAVIERA, B. Venenos: aspectos clínicos e terapêuticos dos acidentes por animais peçonhentos. Rio de Janeiro: EPUB, 1999: 205-23.

74 VILLAROEL MS., ZELANTE F., ROSA RR., FURLANETTO RS. Padronização da avaliação da atividade necrosante de venenos botrópicos e da potência antinecrosante do antiveneno de Bothrops jararaca. Mem. Inst. Butantan, 1978-79, 42-43, 345-55.

75 VITAL-BRAZIL O. History of the primordia of snake-bite accident serotherapy. Mem. Inst. Butantan, 1987, 49, 7-20.

76 WINTER VP. Índice terapêutico veterinário. Rio de Janeiro: EPUB, 2002. 637p. 
R. S. Ferreira Júnior; B. Barraviera. MANAGEMENT OF VENOMOUS SNAKEBITES IN DOGS AND CATS IN BRAZIL. J. Venom. Anim. Toxins incl. Trop. Dis., 2004, 10, 2, p.132.

77 WORLD HEALTH ORGANIZATION. Progress in the characterization of venoms and standardization of antivenoms. Geneva, 1981. (Publication, 58)

78 ZINGALI RB., FRANCISCHETTI IM., CARLINI CR. Biochemical and pharmacological screening of snake (Bothrops) venoms. Characterization of components acting on blood coagulation and platelet aggregation. Braz. J. Med. Biol. Res., 1988, 21, 763-5. 